\title{
IMPROVING STUDENTS' ABILITY IN EXPRESSING OPINION THROUGH GROUP INVESTIGATION AT THE STUDENTS CLASS XI IPA 1 SEMESTER 1 SMA NEGERI 1 ABUNG SEMULI ACADEMIC YEAR 2016-2017
}

\author{
A. Mukhtar Majid *)
}

\begin{abstract}
The objective of this research is to make the teaching learning of English at class XI IPA 1 of SMA Negeri 1 Abung Semuli, academic year 2016-2017 become interesting and effective. The research is classroom action research conducted in two cycles that involves plan, action, observation and reflection. The subject of the research was class XI IPA 1 that consists of 37 students $(25$ females and 12 males ). There were four instruments used in the reseach : teacher's activity, students' activity, active students and learning achievement. This study found that the use of Group Investigation model of learning can increase the effectiveness the English learning process at class XI IPA 1. The effectiveness of learning process is shown by improvement of the achievement at (1) the percentage of teacher's activity that reached the target from $61.95 \%$ (cycle 1) becomes $80 \%$ (cycle 2) or increased $18,05 \%$.(2) The percentage of students' activity in cycle 1 was 41,66 \% became $65,91 \%$ that meant the increased $24,25 \%,(3)$ the persentage of active students also increased from 40,54\% (cycle 1) to 83,78\% (cycle 2), the increase was 43,24\%, and (4) the percentage of speaking score was $24,32 \%$ (cycle 1) became $73,00 \%$ (cycle 2), means the increase wa 48,68\%. The result of learning using Group Investigatio model is achieved through the following stages: (1) pre-activity, teacher prepared students by informing the learning objective, giving motivation, preparing the material and putting the students into groups. (2)main step, the students in group were distributed the topic problem, group presentation, personal task, plenary discussion, conclusion and (3) post-activity, making a resume of the materail and teaching learning reflection
\end{abstract}

Keywords : Group Investigation, interesting, effective and result of learning

\section{PENDAHULUAN}

Berdasarkan dari hasil pengamatan dan pembahasan bersama dalam kegiatan MGMP sekolah, didapatkan bahwa nilai hasil belajar bahasa Inggris dalam skill berbicara di semester 1 tahun pelajaran 2015-1016 masih jauh dari nilai standar menggembirakan (rerata 5,35) kendatipun berbagai upaya pengajaran dilakukan untuk dapat meningkatkan hasil belajar di ranah psikomotorik ini.

Selama proses pembelajaran, dari pengamatan guru menemukan hanya 34\% siswa kelas XI yang mampu mencapai nilai $\geq$ 6.0. Rendahnya hasil belajar siswa tersebut kemungkinan besar disebabkan oleh (1) internal siswa: kurangnya motivasi, minat belajar partisipasi siswa dalam kegiatan belajar dan (2) eksternal siswa: latar belakang 
ekonomi, tujuan masa depan, sehingga siswa nampak tidak siap menerima materi pelajaran. Proses belajar selama ini nampak kurang hidup walaupun telah menggunakan role-play yag termasuk dalam metoda scientifik.

Dari hasil pengamatan bersama teman sejawat dan MGMP, ditemukan bahwa rendahnya hasil belajar siswa tersebut pada umumnya disebabkan kurang maksimalnya peran siswa dalam menggunakan ungkapan, kurangnya kesempatan mengembangkan ide dan kurangnya rasa percaya diri, Disamping siswa selalu melakukan hal yang sama dalam mengkomunikasikan (membaca teks percakapan secara berpasangan di depan kelas), siswapun dihadapkan pada topik problem yang sudah ditentukan dan mungin kurang menarik serta membosankan. Oleh karena itu perlu dicari dan diterapkan metode kolaborasi yang cocok dan menarik yang sesuai dengan pendekatan yang disarankan dalam kurikulum 2013.

Dari hasil pengamatan rendahnya minat, aktifitas dan hasil belajar disebabkan oleh beberapa faktor, yaitu: penyampaian materi yang monoton, jenis kegiatan yang kurang variatif dan inovatif, didominasi oleh siswa yang cukup pandai sehingga kegiatan pembelajaran cenderung membosankan dan tidak menarik.

Berdasarkan kesepakatan dan hasil diskusi bahwa untuk meningkatkan kemampuan anak didik dalam mengungkapkan pendapat, sangat perlu adanya tindakan perbaikan dalam pembelajaran, yakni menggunakan model pembelajaran cooperative learning, dengan metode group investigation dengan alasan model dan metode ini memberi kesempatan siswa untuk menyampaiakan ide, pendapat mereka, menemukan materi yang menarik, siswa mempunyai tanggungjawab pada diri sendiri dan anggota kelompok (Kagan in Yuwono 2011:4 dan Nurulhayati in Yuwono 2011:13).

Berhubungan dengan penerapan group investigation dalam pembelajaran berbicara untuk menyampaikan pendapat, maka permasalahan yang akan didalami adalah" apakah dengan penerapan group ivestigation akan mampu meningkatkan kemampuan siswa dan penampilan guru. Tujuan penelitian ini adalah (1) meningkatkan kemapuan siswa kelas XI dalam mengekspresikan pendapat dan (2) meningkatkan performa guru. Peningkatam ini ditunjukan dengan semakin baiknya cara guru menyampaikan materi, peningkatan partispasi siswa, peningkatan jumlah siswa yang aktip dan peningkatan hasil belajar dari siklus ke siklus.

Pengajaran kecakapan berbicara di sekolah semata-mata bukan hanya untuk mempersiapkan mereka dalam kehiduapn nyata sehar-hari, tapi juga agar siswa dapat menunjukan sikap tanggungjawab, peduli, kerjasama dalam melaksanakan komunikasi fungsional. Kecakapan berbicara sendiri menurut Madsen (1983) bahwa berbicara 
merupakan bagian terpenting dalam pembelajaran, yaitu (1) pre-aktivitas yaitu mempelajari bahasa Inggris. Sementara itu, tahapan 1 dan 2, (2) aktivitas utama yaitu Yorkey menyatakan bahwa kecakapan tahapan 3 dan 4, dan (3) post-aktivitas yaitu berbicara sama dengan kecakapan lainya yang tahapan 5 dan 6 .

harus dipraktikan secara terus menerus.

Kenyataannya memang tidak mudah

\section{METODE PENELITIAN}

untuk mengajarkan kecakapan berbicara

Penelitian tindakan kelas ini dilakukan bahasa Inggris. Fakta menujukan bahwa para secara berkolaborasi dengan rekan sejawat siswa mengalami kesukaran, mengeluh karena sulit, membosankan. Hal tersebut menurut ( Polia 2001:47 ) disebabkan penyampaian pelajaran oleh guru kurang menyenangkan, kurang bervariasi dan tidak menyentuh kehidupan sehari-hari.

Model pembelajaran Group Investigation (GI) menurut Tan, Sharan \& Lee (2007) penerapan group investigation dalam pembelajaran di kelas dengan cara menempatkan siswa dalam kelompokkelompok untuk memecahkan permasalahan umum, sebagai contoh korupsi dan narkoba yang pada akhirnya harus dipresentasikan di depan kelas dan kemungkinan menumbuhkan debat positif. Sementara itu, Slavin (2011), menyatakan dalam aplikasinya group investigation mengarahkan siswa untuk bekerja dengan enam tahapan, yaitu: (1) mengidentifikasi topik permasalahan, (2) merencanakan tugas yang akan dipelajari, (3) melakukan investigasi, (4) mempersiapkan laporan, (5) mempresentasikan laporan akhir dan (6) evaluasi.

Dalam konteks penelitian ini, ke enam tahapan ini dirangkum menjadi tiga langkah guru-guru bahasa Inggris di SMA Negeri 1 Abung Semuli, Lampung Utara. Subjek dari penelitian ini adalah siswa kelas XI IPA 1semester 1 Tahun Pelajaran 2016-2017 selama kurang lebih 2 bulan, dari September 2016 sampai dengan Oktober 2016. Tahapan yang dipergunakan adalah: (1) persiapan (penentuan subjek, ijin penelitian, perangkat penelitian dan pembelajaran), (2) pelaksanaan dan (3) pelaporan.

Dalam pelaksanaan penelitian ini, dibagi menjadi dua siklus tindakan dimana setiap siklus mempunyai tiga tahapan, yaitu : perencanaan, pelaksanaan dan observasi. Setiap siklus terdiri dari 3 pertemuan dimana pertemuan ke 3 dipergunakan untuk presentasi dan penilaian yang disesuaikan dengan langkah ke 5 pendekatan scientifik yaitu mengkomunikasikan. Didalam proses pelaksanaan tiap siklus guru didampingi oleh pengamat untuk mengobservasi kekurangan dan kelebihan baik kegiatan guru , kegiatan siswa, cara penerapan model pembelajaran. Hasil pengamatan tadi ditindak lanjuti dengan pembahasan untuk pertimbangan dan 
perbaikan dalam pelaksanaan siklus berikutnya.

Dari data yang didapat, dilakukan analisis sebagai bahan refleksi. Analisis dilakukan dengan cara membandingkan perolehan hasil pencapaian dengan indikator yang telah ditentukan sebelumnya.

Indikator keberhasilan tindakan kelas ini adalah adanya peningkatan hasil belajar dan aktivitas pada setiap siklusnya, dan $\geq 65$ $\%$ siswa mendapat nilai $\geq 6,00$. Baik untuk ranah psikomotorik.

\section{HASIL DAN PEMBAHASANNYA}

Dalam pelaksanaan pembelajaran bahasa Inggris dengan ketrampilan berbicara menyampaikan pendapat digunakan tiga tahapan, yaitu: tahapan awal (pre-activity), tahapan inti (main activity) dan tahapan akhir (post-activity). Hasil pengamatan guru dan siswa dalam siklus 1 dan siklus 2 dapat dilihat dalam tabel berikut:

\section{Tabel 1: Hasil Observasi Aktifitas Guru dan Siswa}

\begin{tabular}{|l|l|l|l|l|l|}
\hline No & Aktifitas & \multicolumn{3}{|l|}{ Siklus } & \multicolumn{2}{|l|}{ Siklus } & 2 \\
\hline & & Nilai & $\%$ & Nilai & $\%$ \\
\hline 1 & Guru & 40 & 61,95 & 64 & 80 \\
\hline 2 & Siswa & 10 & 41,66 & 29 & 65,91 \\
\hline
\end{tabular}

Gambar 1 : Peningkatan Aktifitas Guru dan Siswa

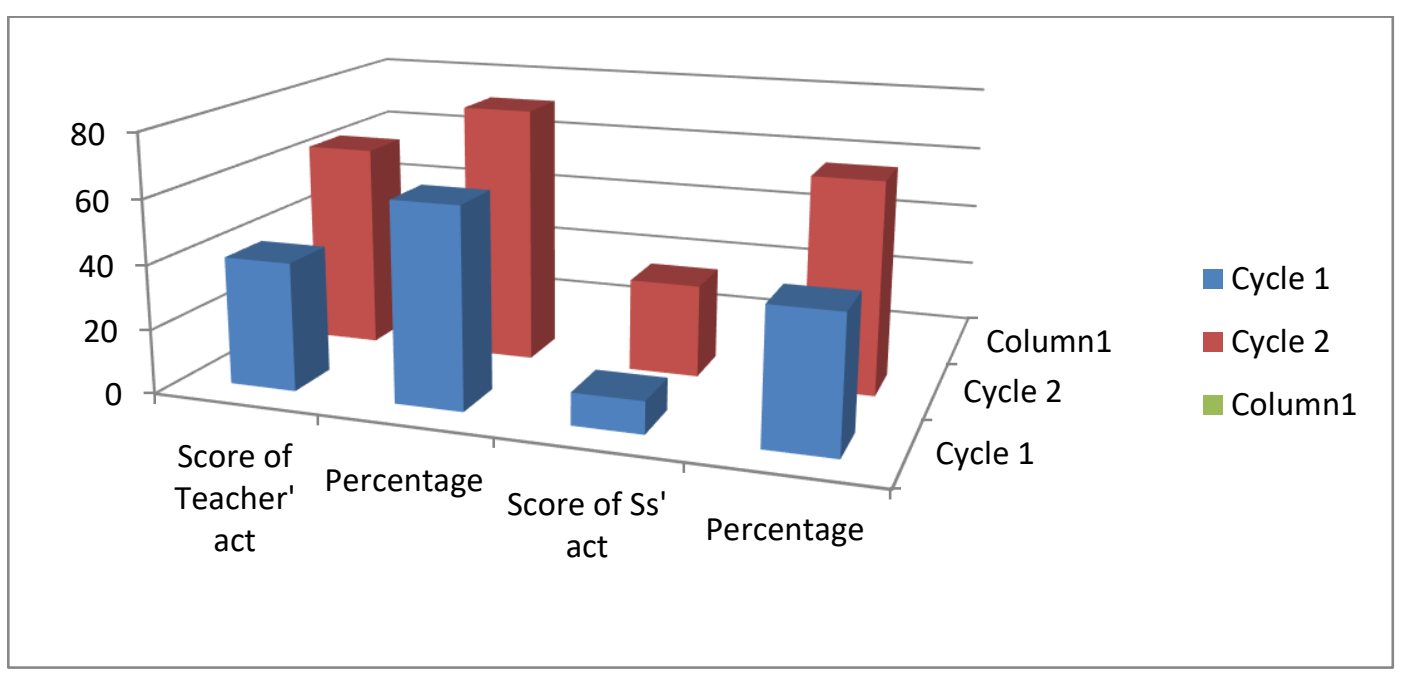

Dari hasil pengamatan diperoleh matang, penguasaan materi dan model adanya peningkatan pada aktifitas guru pembelajaran, pemberian motivasi pada sebesar 18,05\%, yang disebabkan karena siswa. Sementara itu, peningkatan juga guru telah mempunyai persiapan yang lebih terdapat pada tingkat aktifitas siswa yaitu 
sebesar $24,25 \%$, yang dikarenakan oleh telah termotovasi, pentingnya membantu teman (social interact) sebagai tanggungjawab. Gurupun telah menyapaikan tujuan pembelajaran sebagai target sehingga siswa lebih apat memfokuskan diri pada peran masing-masing (sebagai ketua, pembicara dan moderator) untuk dapat mencapai target yang telah ditentukan, lebih berani dalam menyampaikan pendapat. Kondisi belajar ini lebih hidup dan menarik. Hal ini sewsuai dengan apa yang disampaikan oleh Jihad (2008:175) bahwa rumusan tujuan pembelajaran yang jelas akan melukiskan perubahan tingkah laku yang diharapkan dari siswa setelah pembelajaran dan membantu guru dalam menyusun kegiatan belajar anak didiknya.
Penyampaian tujuan pembelajaran ternyata menjadi sumber motivasi bagi siswa dalam belajar. Bandura dalam UNO (2008:45) menyatakan bahwa sumber motivasi yaitu hasil hasil yang dapat diprediksi dan prilaku yang dapat dikerjakan dan tujuan yang dapat ditetapkan sebagai standar pribadi. Hal ini terlihat pada keaktipan siswa yang ditunjukan dengan antusiasme mereka dalam pembelajaran . Tingkat keaktipan siswa inipun mengalami peningkatan berdasarkan hasil observasi dalam siklus 1 dan siklus 2 seperti dalam tabel berikut:

Tabel 2: Hasil Obeservasi Keaktipan Siswa

\begin{tabular}{|c|l|l|l|l|l|}
\hline \multirow{2}{*}{ No } & \multirow{2}{*}{ Komponen } & \multicolumn{2}{|c|}{ Siklus 1 } & \multicolumn{2}{c|}{ Siklus 2 } \\
\cline { 3 - 6 } & $\sum$ siswa & $\%$ & $\sum$ siswa & $\%$ \\
\hline 1 & Aktip & 15 & 40,54 & 32 & 83,78 \\
\hline 2 & Tidak aktip & 22 & 59,46 & 5 & 13,51 \\
\hline
\end{tabular}

Pada kegiatan utama, guru sebagai facilitator menditribusikan sebuah topik beserta sub topik sebagai bahan diskusi (Korupsi sebagai bahan di siklus 1 dan Narkoba sebagai bahan di siklus 2). Semua kegiatan dan langkah kegiatan pada siklus 1 dan 2 hampir sama, yakni kegiatan (1) preactivity dilakukan untuk mengabsen siswa, memotivasi, menyebutkan tujuan pembelajaran dan materi yang akan dipelajari, (2) kegiatan inti: mengamati, menanya, mengekplrasi, mengasosiasikan dan mengkomunikasikan (3) kegiatan akhir :melakukan refleksi kegiatan pembelajaran. Pemberian perlakuan setalah siklus 1 dilakukan dengan menjelaskan secara jelas dan rinci tentang group investigation dan pemberian samangat dan motivasi bagi anak 
didik yang kurang aktip serta perlunya membantu teman (social interact) bagi siswa yang selalu mendominasi/lebih pandai.

Sebagai hasil pemberian perlakuan hasil presentasi kelompok dalam kegiatan mengkomunikasi kan mengalami peningkatan. Penilaian yang mencakup aspek kosakata, fluency, pelafalan dan tata bahasa dengan masing-masing kriteria, peningkatannya dapat dilihat di alam tabel berikut:

Tabel 3. Hasil Penilaian Presentasi

\begin{tabular}{|l|l|l|l|}
\hline & Score & $\begin{array}{l}\text { Siklus } \\
1\end{array}$ & $\begin{array}{l}\text { Siklus } \\
2\end{array}$ \\
\hline $\begin{array}{l}\text { E siswa yang } \\
\text { memperoleh } \\
\text { nilai }\end{array}$ & $\leq 60$ & 28 & 10 \\
\hline Dalam persen & & $75,68 \%$ & $27,03 \%$ \\
\hline $\begin{array}{l}\sum \text { siswa yang } \\
\text { memperoleh } \\
\text { nilai }\end{array}$ & $\geq 60$ & 9 & 27 \\
\hline Dalam persen & & $24,32 \%$ & $72,97 \%$ \\
\hline
\end{tabular}

Sedangkan untuk nilai rata-rata yang diperoleh siswa dalam dua siklus (siklus 1 nilai rata-rata $=53,03$, sedang siklus 2 dengan rata-rata $=72,82)$ digambarkan sebagai berikut:

\section{Gambar 2: Nilai Hasil Belajar Siswa}

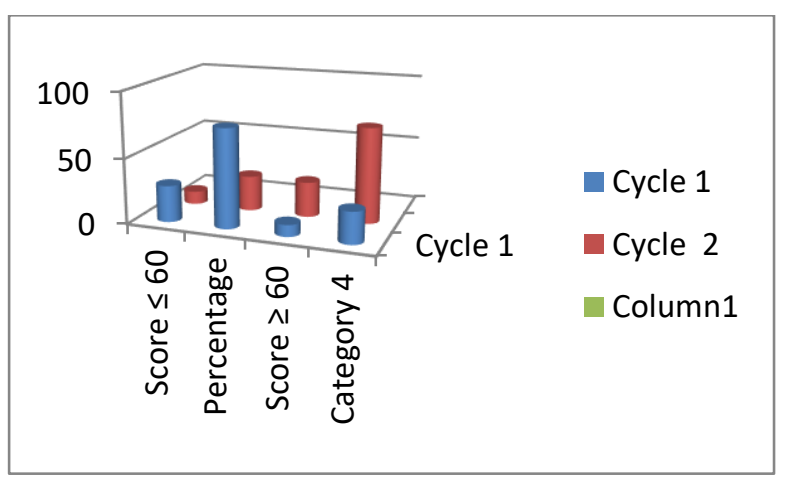

Gambar 3. Nilai rata-rata hasil belajar siswa siklus 1 dan 2

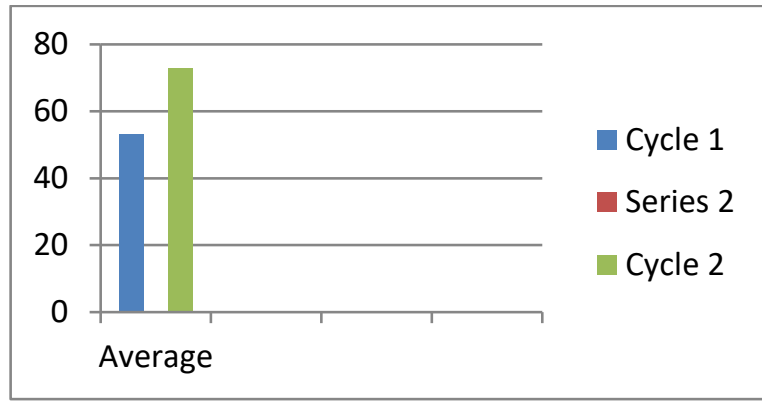

Berdasarkan hasil penilaian pada akhir siklus 1, diperoleh nilai rata-rata 53,03 (Gambar 2) dan jumlah siswa yang memenuhi kriteria ketuntasan belajar (berbicara) yang ditetapkan guru mata pelajaran $(\geq 60,00)$ sebanyak 9 orang atau 24,32\% (Tabel 3). Bila dilihat dari ketuntasan belajar yang ditentukan yaitu 60,00, maka hasil yang diperoleh pada siklus 1 belumlah memuaskan, karena masih dibawah indikator keberhasilan yang ditentukan dalam penelitian ini, yaitu $65 \%$.

Faktor tidak tercapainya indikator keberhasilan yang diihat dari nilai psikomotorik diatas karena kurang maksimalnya metode yang dilaksanakan dalam pembelajaran.

Dari hasil refleksi pada siklus 1, guru dan pengamat menemukan penyebab faktor kegagalan, yaitu: (1)guru peneliti belum berperan sebagai fasilitator, masih mendominasi jalannya pembe; ajaran, (2) guru kurang memantau dan membantu kesulitan siswa (helper), (3) guru kurang memberikan waktu yang cukup (manager) dan (4) kurang berperan sebagai source/ nara 
sumber yang menyajikan dan memberikan penjelasan.

Hasil rata-rata yang diperoleh siswa pada akhir siklus 2 adalah 72,81 (Tabel2, gambar 2) dan jumlah siswa yang memenuhi kriteria ketuntasan belajar dengan nilai $\geq$ 60,00 sebanyak 27 orang atau 72,97\% dan ini sudah berarti memuaskan untuk ranah psikomotorik.

Pembelajaran dalam kelompok mengarahkan siswa untuk berlatih ketrampilan, berkomuikasi, mempercayai orang lai dan ketrampilan mengelola konflik. Hal ini selaras dengan apa yang disampaikan oleh Bruner dalam Nur (2000) bahwa interaksi dalamkelompok (social interact) merupakan hal penting dalam pembelajaran karena berpengaruh pada prilaku dan pemecahan maslah oleh siswa.

Semakin terampilnya guru dalam merencanakan, melaksanakan dan merefleksi, merupakan perubahan pengelolaan pembelajaran menjadi lebih efektip dari sebelumnya. Dan ini merupakan dampak positip penelitian bagi guru, karena semakin terampil mengelola pembelajaran.

Dampak pengiring yang dialami siswa adalah tidak saja dilihat dari semakin meningkatnya aktifitas siswa, minat belajar dan hasil belajar yang diperoleh, tetapi juga kemampuan siswa dalam memecahkan masalah, kerjasama dalam kelompok da keberanian dalam menyampaikan pendapat.
Hasil penelitian tindakan yang dilaksanakan secara kolaboratip dengan rekan guru MGMP, mendekatkan teori-teori yang didapat di perguruan tinggi dengan kenyataan di lapangan. Secara keseluruhan, hasilpenerapan metode Group Investigation telah memberikan dampak positip bagi peningkatan hasil belajar, aktifitas dan minat belajar siswa yang bisa menjadi bekal untuk menjalani kehidupan nanti.

\section{KESIMPULAN DAN SARAN}

Dari hasil penelitian dan pembahasan yang telah dijabarkan sebelumnya, dapat disimpulkan bahwa pengimpelementasian metode Group Investigation dapat meningkatkan efektifitas pembelajaran bahasa Inggris di kelas XI IPA 1 tahun 20162017. Keefektifitasan tersebut ditandai oleh (1) prosentas ketuntasan belajar siswa $(\geq 60)$ sebesar $24,32 \%$ pada siklus 1 menjadi 72,97 $\%$, pada siklus (2) nilai rata-rata hasil belajar 53,03 pada siklus 1 menjadi 72,81 pada siklus 2.(3) Aktifitas siswa juga meningkat dari $41,66 \%$ pada siklus 1 menjadi $65,91 \%$ pada siklus 2 dan (4) minat/keaktipan siswa meningkat dari 40,54\% (siklus 1) menajdi $83,78 \%$ (siklus 2). 
Gambar 3. Persentase Kenaikan semua aspek selama peneitian

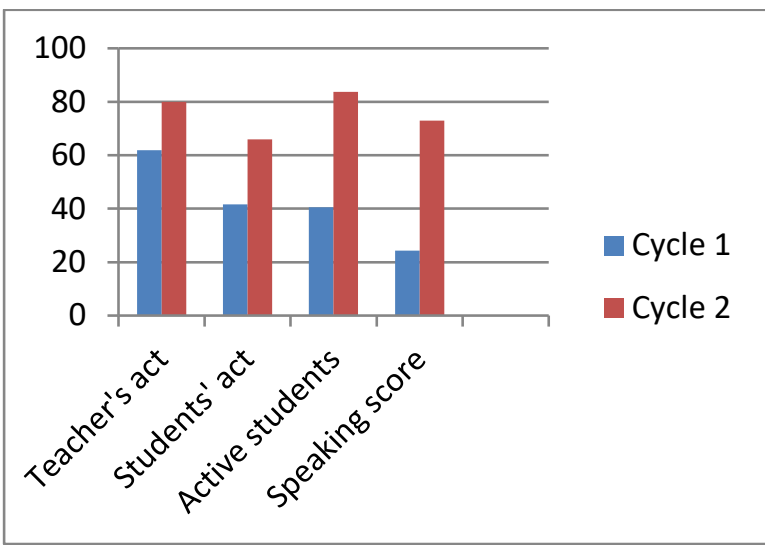

Prosedur yang diterapkan dalam

pembelajaran dengan penerapan Group

Investigation dalam penelitian ini adalah (1)

tahap awal: guru mempersiapkan siswa dalam pembelajaran dengan kegiatan mengkmunikasikan tujuan pembelajaran, membrikan motivasi, melihat kembali materi sebelumnya dan mengarahkan siswa berkelompok dalam pembelajaran, (2) tahap inti, siswa secara berkelompok diberikan masalah kontekstual yang masih hangat dibicarakan, presentasi masing-masing kelompok, diskusi kelas dan penyimpulan dan (3) tahap akhir, pembuatan rangkuman dan refleksi pembelajaran.

Dari kesimpulan di atas, beberapa saran yang berhubungan dengan hasil penelitian, sebagai berikut: (1) hasil penelitian menyarankan metode group invstigation untuk dijadikan salah satu alternatip pengajaran kecakapan berbicara, (2) untuk menjadi efektip guru harus memerankan sebagai motivator, fasilitator, manager, helper dan nara sumber, dan (3) guru harus lebih kreaitip untuk menciptakan suasana kelas menjadi lebih hidup.

\section{Daftar Pustaka}

Arikunto, Suharsini. 2005. Managemen Penelitian, Jakarta, Rineka Cipta.

Brown, Dauglas H. 2004. Language Assessement Principle and Classroom Practice. San Fransisco State Univerisity:Longman.

Cameron, Lynne, 2002. Teaching Language To Young Learner, Cambridge: Cambridge University Press.

Harmer, Jeremy. 2007. How To Teach English New Edition, Pearson Longman.

Hatch, Evelyn and Hossein Farhady, 1982. Research Design and Statistics for Applied Linguistics. London: Newbury House Publisher, Inc.

Kayi, Hayriye. 2006. Teaching Speaking: Activities to Promote Speaking in Second Language.

Komaidi, Didik dan Wahyu Wijayanti. 2011. Teori, Praktek dan Contoh PTK. Yogjakarta: Sabda Media.

Slavin, Robert R. 2005. Cooperative Learning, Bandung: Nusa Media.

Suprijono, Agus. 2009. Cooperative Learning, Surabaya, Pustaka Belajar.

Uno, Hamzah. 2008. Model Pembelajaran, Jakarta:Bumi Aksara. 